\section{A conjuração dos imbecis}

Texto publicado pelo jornal francês Libération em 7 de maio de 1997. Tradução de Juremir Machado da Silva.
Jean Baudrillard Sociólogo
As DUAS SITUAÇõEs são uma tão crítica e insolúvel quanto a outra: a nulidade da arte contemporânea e a impotência do político face a Jean-Marie Le Pen ${ }^{1}$. Situações que se intercambiam e resolvem por transfusão; a impotência em opor o que quer que seja de político a Le Pen desliza para o terreno da cultura e da Santa Aliança cultural. A penas um pensamento reacionário e irracional, ou mesmo fascista, poderia pôr em xeque a arte contemporânea...

O que se pode opor a essa conjuração respeitosa de imbecis? Nada, infelizmente, pode corrigir esse mecanismo de perversão intelectual, dado que ele se inspira na má consciência e na impotência de nossas elites "democráticas" para resolver tanto o impasse da arte quanto o impasse político da luta contra a Frente Nacional. A solução mais simples consiste em confundir os dois problemas na mesma vituperação moralizante. A verdadeira questão torna-seentão: não se podemais "abrir", preferir o insólito, o insolente, o heterodoxo ou o paradoxal sem ser automaticamenteconsiderado deextremadireita (o que é, diga-se de passagem, uma homenagemà extrema-direita)? Por quetudo o que é moral, conforme e conformista, ou tradicionalmente de direita, tornou-se de esquerda?

Revisão dolorosa: antes, a direita encarnava os valores morais, ea esquerda, ao contrário, uma certa exigência histórica e política contraditória; hoje, a esquerda, despojada de todaenergiapolítica, tornou-sepurajurisdição moral, encarnação dos valores universais, campeã do reino da Virtude e defensora dos valores museais do Bem e do Verdadeiro; jurisdiçãoquepodeexigir prestação decontas de todo mundo sem ter de responder diante de ninguém. A ilusão política da esquerda, congelada durante vinte anos na oposição, revelou-se, com a chegada ao poder, portadora, não dosentido daHistória, masde 
uma moral da História. Moral da Verdade, do Direito e da boa consciência - grau zero do político e, certamentemesmo, ponto mais baixo na genealogia da moral. Essa moralização dos valores equivale a uma derrota histórica da esquerda (e do pensamento). Mesmo a realidade, o princípio de realidade, converteu-se em artigo de fé. Questione-se a realidadedeuma guerra; ojulgamento não se faz esperar: traição à lei moral.

A esquerda está politicamente tão desencarnada quanto à direita. Onde foi parar o político? Eh, bem, do lado da extrema-direita. Como dissecompertinênciaBruno Latour no M onde, o único discurso político na França, hoje, é o de Le Pen. Todos os outros são discursosmoraisepedagógicos, discursosde alfabetizadores e de pregadores de sermão, de administradores e de programadores. Fadado ao mal e à imoralidade, Le Pen abocanha toda a perspectiva política, o saldo de tudo o que é esquecido, ou francamente rejeitado, pela política do bem e das Luzes. Quanto mais se endurece a coalizão moral contra ele - signo de impotência política maiseletira proveito político daimoralidade, de ser o único do lado do mal. Quando a direita col ocou-se ao lado dos valores morais e da ordem estabelecida, a esquerda não hesitou, outrora, em desafiar esses mesmos valores morais em nome de valores políticos. Hoje, a esquerda é vítima do mesmo deslizamento, do mesmo despojamento: investida pela ordem moral, só pode ver cristalizar-se alhures a energia política repelida; e cristalizar-se contra ela.

A o encarnar oreino daVirtude, queétambém o dagrandehipocrisia, a esquerda alimenta o Mal. Se Le Pen não existisse, seria preciso inventá-lo. É ele que nos libera de toda uma parte maléfica de nós mesmos, da quintessência do quehá de pior em nós. Desseponto de vista, deveríamos anatematizá-lo - mas seeledesaparecesse, pobres denós, entregues a todos os nossos vírus racistas, sexistas, nacionalistas (o quinhão de todos) ou simplesmente à negatividade assassina do ser social. Nisso, ele é o espelho da classe política, que exorciza nele os seus próprios males, como nós exorcizamos nela, na classe política, toda corrupção inerente ao funcionamento social. M esma função corruptora, mesma função de catarse. Querer extirpar isso, querer purificar a sociedadeemoralizar a vida pública, querer liquidar o queencarna o mal, demonstra o desconhecimento total dosmecanismosdomal e, portanto, daprópria forma do político.

Os antilepenistas, apostando na denúncia unilateral eignorandotudo da reversibilidade do mal, deixaramo monopólio desteaLePen, quegozaassim, graçasàsua exclusão, deuma posição inexpugnável. A classe política, ao estigmatizá-lo emnomedaVirtude, asseguraIhea posição mais confortável, bastando-Ihe recolher toda a carga simbólica de ambivalência, dedenegação do mal edehipocrisia produzidas espontaneamente em seu benefício, como se fossem encomendadas por ele, seus adversários reclamando-sedo bom lado e da boa causa. A energia de LePen vem dos seus próprios inimigos, que se apressam em canalizar os próprioserros em benefício dele. Ainda não compreenderam que o bem não resulta jamais de uma evicção do mal, que alcança sempreumarevancheexplosiva, mas de um tratamento sutil do mal pelo mal.

Tudo isso para dizer quese LePen representa a encarnação da besteira e da nulidade certamente esta é a dos outros, os que ao denunciá-lo denunciamaprópriaimpotência e a própria besteira; ao mesmo tempo, transparece o absurdo de combatê-lo frontalmente, sem nada ter compreendido desse jogo decadeirasdiabólicas, al imentandoassim os próprios fantasmas, o próprio duplo negativo, numa falta aterradora de lucidez. Quem comanda esse efeito perverso estando a esquerda bloqueada na denúncia, enquanto Le Pen detém o monopólio da enunciação; um tirando todos os benefícios do crime, a outra, todos os efeitos negativos da recriminação; ele explodindo no mal, ea esquerda aferrando-se ao vitimal. 
U maverdadebastantesimples: ao encurralar LePen num gueto, éa esquerda democrática queseencerra, quesedesigna como potência discriminatóriaequeseexilanasuaobsessão. Ela dá automaticamenteao outro o privilégio da injustiça. E Le Pen não deixa de tirar conclusões em seu benefício dessa legalidade republicana, mas é sobretudo no prestígio ilegal, imaginário, mas muito profundo, do perseguido que ele se instala, tão bem que pode gozar ao mesmo tempo dos benefícios da legalidade e da ilegalidade. Desse ostracismo, extrai uma liberdade de expressão, umainsolência dejulgamento que a esquerda não se permite. Exemplo desse pensamento mágico, simulacro, naatualidade de pensamento político, aparece na crítica a LePen pelaexclusão dosimigrantes. Masesta é apenas uma gota d'água no processo de exclusãosocial dominanteemtodososníveis. ${ }^{2}$

Desse processo complexo e inextricável de responsabilidade coletiva, somos todos cúmplices e vítimas. É portanto tipicamente mágico conjurar essevírus, quese dissemina por toda parte em função mesmo de nosso "progresso" social e técnico, exorcizar essa maldição da exclusão, e nossa impotência diante dela, num homem, numa instituição ou num grupo execráveis, quaisquer que sejam, um cancro que bastaria operar por ablação, quando na verdade as metástases já estão por tudo. A Frente Nacional apenas segue as vias rasgadas pelas metástases, com mais violência na medida em que cremos ter extirpado o abscesso e que os gérmenes se espalham por todo o organismo. Sem contar que essa projeção mágica sobre a FN abusa exatamente dos mesmos métodos desta em relação aos imigrantes. É preciso desconfiar dessa astúcia da contaminação que, pela simples transparência do mal, faz com queo positivo setransformeem vírus negativo, ea exigência de liberdade em "despotismo democrático". Sempre essa reversibilidade, essa espiral sutil do mal, daqual ainteligência racional não desconfia (enquanto toda a patologia moderna tanto nos ensina sobre o corpo físico, nada consideramos quanto ao corpo social).

Devemos, paracontinuar napolítica, protegernos da ideologia ever as coisas em termos de física social. N ossa sociedadedemocrática éa stase; LePen éa metástase. A sociedadeglobal perece por causa da inércia e da imunodeficiência. Le Pen significa a transcrição visível desse estado viral, sua projeção espetacular. Como nos sonhos, representa a figuração burlesca, alucinatória, desseestado latente, dessa inércia silenciosa feita de integração forçada e de exclusão sistemática emdosesiguais. A esperança, nestasociedade, de reduzir as desigual dades sociais tendo-se (quase) definitivamenteafastado, nãohárazão para surpreender-se ao ver o ressentimento deslocar-se para as desigualdades raciais. A falência do social produz o sucesso do racial (e de todas as formas de estratégias fatais). Nesse sentido, Le Pen é o único analisador selvagem dasociedade. Queelesejaa extremadireita, éatristeconseqüência dainexistência desde de algum tempo de esquerda e de extrema-esquerda.

Certamente não seriam os juizes, nem os intelectuais, mas somente os imigrantes que estariamtambémem posição deanalisadores, masum certo pensamento correto apropriouse amplamente deles. Le Pen é único que opera uma redução radical da distinção direita/ esquerda - redução à revelia, certo, mas a crítica sem apelação feita nos anos 60 , e em 68, infelizmente desapareceu da vida política. Ele recupera assim uma situação de fato quea classe política se recusa a enfrentar (ela faz mesmo tudo para apagá-la através das eleições), mas da qual seránecessário um dia tirar as conseqüências extremas. Se um dia a imaginação política, a exigência e a vontadepolíticastiverem uma oportunidade de repercutir será baseada na abolição dessa distinção fóssil que se auto-anulou e desautorizou ao longo das décadasequesóse sustenta pela cumplicidade na corrupção. Distinção apagadanosfatos, masque, através de um revisionismo incurável, tenta-se obsessivamenteressuscitar, fazendoassimde 
Le Pen o gerador da única nova ocorrência política. Como setodo mundofossecúmplice para levar ao naufrágio o que ainda resta da democracia, certamente para dar a ilusão retrospectiva de que ela de fato existiu.

Há uma possibilidade de tirar as conseqüências dessa situação extrema (mas original) que não seja através do médium alucinatório deLePen, istoé, deoutramaneira que não por uma conjuração mágica na qual se esgotam todas as energias? Como não sucumbir a essa excrescência viral de nossos própriosdemôniosa não ser reconsiderando, para além da ordem moral edo revisionismo democrático, essa análise selvagem da qual Le Pen e a FN nos despojaram?

\section{Notas}

1 [Líder da extrema-direita francesa esímbolo da negação do cosmopolitismo de uma nação que cultua a imagem de pátria da cultura e dos Direitos do Homem, N.T.].

2 A própriaexclusão, ao mesmo tempo quea fratura social, foi excluída pelo decreto de dissolução da Assembléia [Baudrillard referese ao decreto do presidente Jacques Chirac que, neste ano, dissolveu a Assembléia francesa, determinando novas eleições legislativas e a formação de um novo Governo, N.T.].

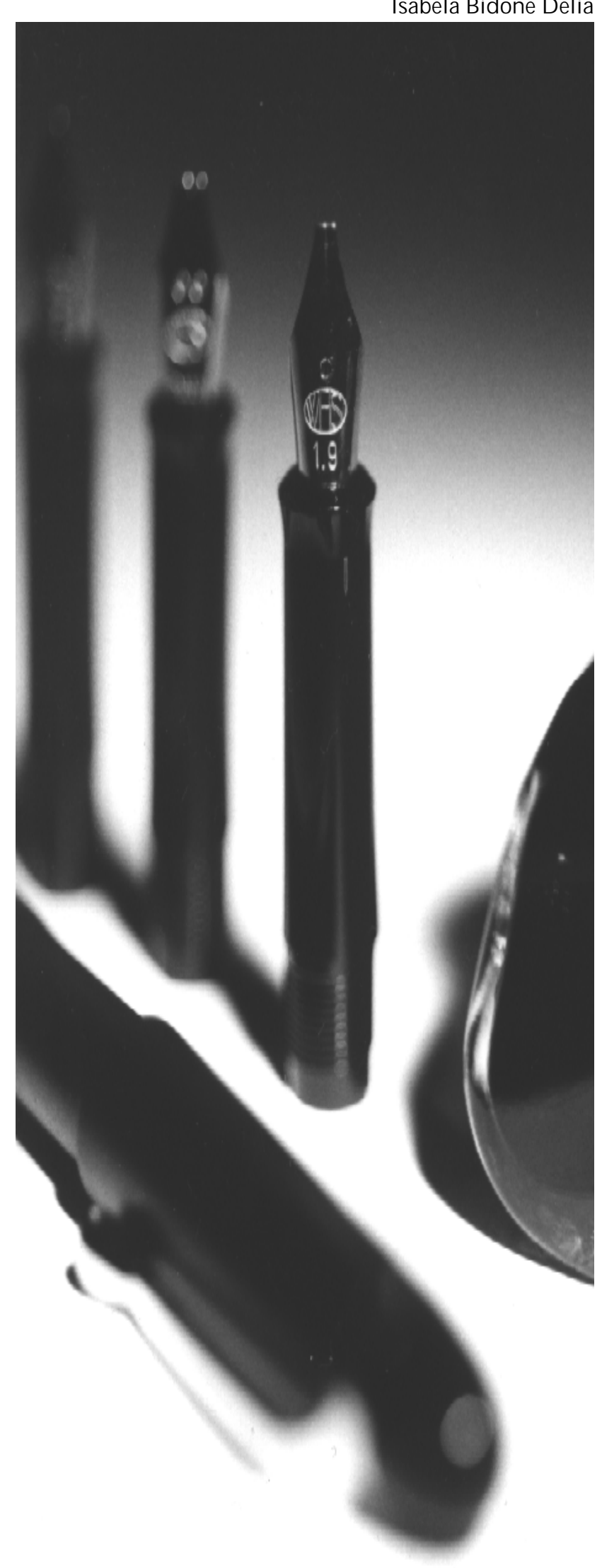

